\title{
A combination of Bohr and Haldane effects provide a physiologic explanation for the increase in arterial oxygen saturation when a face mask is added to a high-flow nasal cannula in severely hypoxemic COVID-19 patients
}

\author{
Pablo Born and Ricardo Castro * (1)
}

\section{Dear editor:}

We read with great interest the article by Dogani et al. on the potential effect of adding an oxygen mask -without supplemental oxygen - to a high-flow nasal cannula on the improvement of oxygenation, in patients with acute hypoxemic respiratory failure due to COVID-19 [1]. We would like to share some comments considering: (a) the improbability that the oxygenation improvement could be related to a real rise in $\mathrm{PaO}_{2}$ by the use of a mask (although neither $\mathrm{PaO}_{2}$ nor $\mathrm{pH}$ data were provided), and (b) the lack of a straightforward physiological mechanism for this observation. We think that the explanation for the observed increase in the arterial oxygen saturation $\left(\mathrm{SaO}_{2}\right)$ reported was due to a left shift on the hemoglobin dissociation curve, solely under the operation of Bohr and Haldane principles [2, 3].

We propose that an improvement in $\mathrm{SaO}_{2}$ with a stable $\mathrm{PaO}_{2}$ came secondary to a rising in arterial $\mathrm{pH}$ according to the Bohr effect, or to a displacement of $\mathrm{CO}_{2}$ bound

This comment refers to the article available online at https://doi.org/10.1186/ s13054-021-03738-8.

${ }^{*}$ Correspondence: rcastro@ucchristus.cl

Departamento de Medicina Intensiva, Unidad de Paciente Crítico Hospital Clínico UC-CHRISTUS, Pontificia Universidad Católica de Chile,

Diagonal Paraguay \#362, Piso 6, Santiago, RM, Chile to hemoglobin (the carbamino compound) by an increase on blood oxygenation (Haldane) (Figs. 1 and 2), while keeping the arterial $\mathrm{CO}_{2}$ content relative stable. In fact, final $\mathrm{PaCO}_{2}$ remained unchanged in the eighteen patients of the study.

If we assume an increase in alveolar ventilation by a more efficient high-flow nasal cannula performance (concurring with the authors on a significant reduction of ambient air entrainment), plasma alkalinization came forth naturally: alongside with a ventilatory-driven $\mathrm{PaCO}_{2}$ decrease, protonated hemoglobin released $\mathrm{H}+$ which increased its affinity for $\mathrm{O}_{2}$ (the Bohr effect), increasing $\mathrm{SaO}_{2}$ consequently. On the $\mathrm{CO}_{2}$ metabolic side, this effect shifted the bicarbonate buffer equilibrium towards $\mathrm{CO}_{2}$ formation from carbonic acid, producing the release of this gas from erythrocytes that resulted in a slight rise in $\mathrm{PCO}_{2}$. Furthermore, as hemoglobin carried more oxygen, amino group-bound $\mathrm{CO}_{2}$ became displaced into its dissolved fraction (Haldane effect), all of which induced an increase in $\mathrm{PaCO}_{2}$ which would match the previous ventilatory $\mathrm{PaCO}_{2}$ decrease. As a final result, a slight or no major change in $\mathrm{PaCO}_{2}$ was observed.

Moreover, progressive hypoxemia correction may have produced an adaptive decrease on original author(s) and the source, provide a link to the Creative Commons licence, and indicate if changes were made. The images or other third party material in this article are included in the article's Creative Commons licence, unless indicated otherwise in a credit line to the material. If material is not included in the article's Creative Commons licence and your intended use is not permitted by statutory regulation or exceeds the permitted use, you will need to obtain permission directly from the copyright holder. To view a copy of this licence, visit http://creativecommons.org/licenses/by/4.0/. The Creative Commons Public Domain Dedication waiver (http://creativeco mmons.org/publicdomain/zero/1.0/) applies to the data made available in this article, unless otherwise stated in a credit line to the data. 


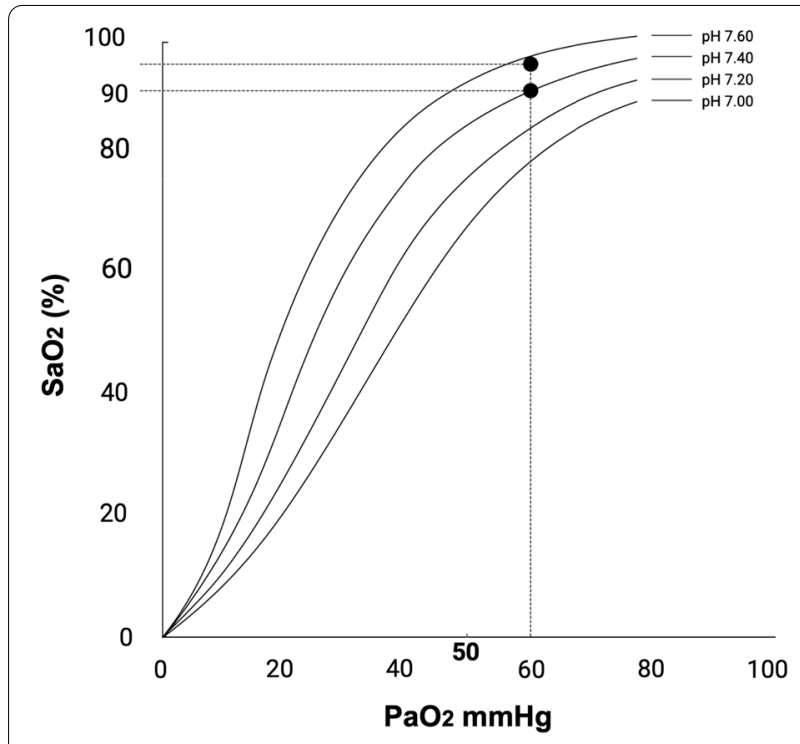

Fig. 1 Hemoglobin dissociation curves according to acid-base status. Figure shows the arterial oxygen saturation $\left(\mathrm{SaO}_{2}\right)$ variation (approximate values for the study by Dogani [1]) for a given $\mathrm{PaO}_{2}$ depending on arterial pH. Note: Figures drawn by Ricardo Castro

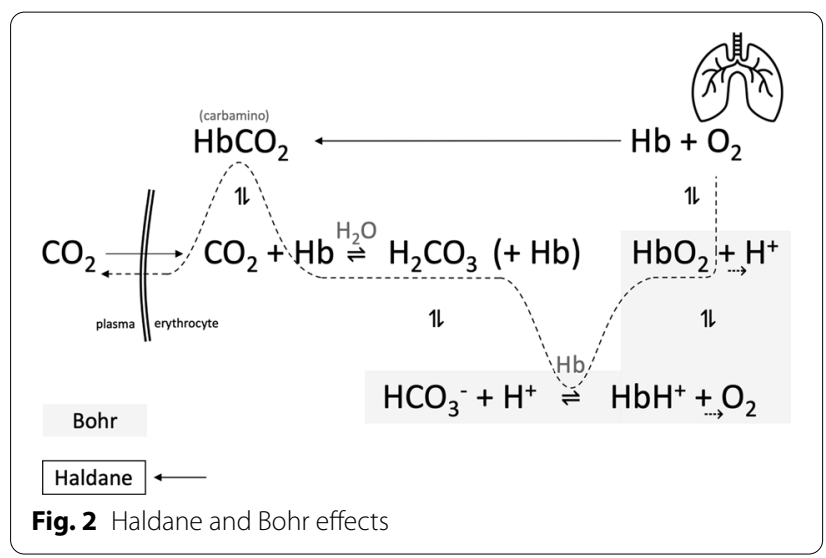

2,3-diphosphoglycerate which left-shifted the hemoglobin dissociation curve further [4].

We acknowledge that we are presenting a theoretical model attempting to fill the gaps of an objectively documented observation, despite some lacking data. However, the combination of available data with classic physiologic principles provides another explanation for this interesting and clinically relevant phenomenon.

\section{Authors' response letter}

Besarta Dogani, Fredrik Månsson, Fredrik Resman, Hannes Hartman, Johan Tham and Gustav Torisson
Dear editor,

We thank Dr. Born and Dr. Castro for the input on our research letter describing an increased $\mathrm{SaO}_{2}$ when adding a mask to high-flow nasal cannula (HFNC) in patients with severe COVID-19 [1]. In a well-reasoned argument, Dr. Born and Dr. Castro propose that the increase in $\mathrm{SaO}_{2}$ may be due to a left shift in the hemoglobin dissociation curve, i.e. an increase in $\mathrm{SaO}_{2}$ with a stable $\mathrm{PaO}_{2}$ [5]. To expand the discussion, we would like to provide data regarding $\mathrm{PaO}_{2}$ and $\mathrm{pH}$, from the arterial blood gases taken at baseline and after 30 min with mask.

In all participants, $\mathrm{PaO}_{2}$ increased after $30 \mathrm{~min}$, with a mean difference of $3.2 \mathrm{KPa}$ (95\% CI 2.2-4.2), equivalent to $\sim 24 \mathrm{mmHg}(95 \% \mathrm{CI} 16-32)$, see Fig. 3. This result is in line with the study by Montiel et al., who applied a surgical mask on top of HFNC [6]. In their study, $\mathrm{PaO}_{2}$ increased in all participants as well, with a mean difference of $20 \mathrm{mmHg}$ (95\% CI 13-26). Furthermore, in our study there was a slight decrease in the average $\mathrm{pH}$ after 30 min, from 7.480 to 7.471 , with a mean difference of -0.009 ( $95 \%$ CI -0.018 to -0.001$)$. Therefore, we consider it unlikely that a left shift in the hemoglobin dissociation curve would fully explain the observed phenomenon.

We hypothesised that the mask could minimise entrainment of room air, especially when mouth-breathing, although we have no data to support this hypothesis. To the best of our knowledge, no studies have measured fiO2 in COVID-19 patients with HFNC. Studies in healthy volunteers suggest that $\mathrm{fiO} 2$ may decrease upon

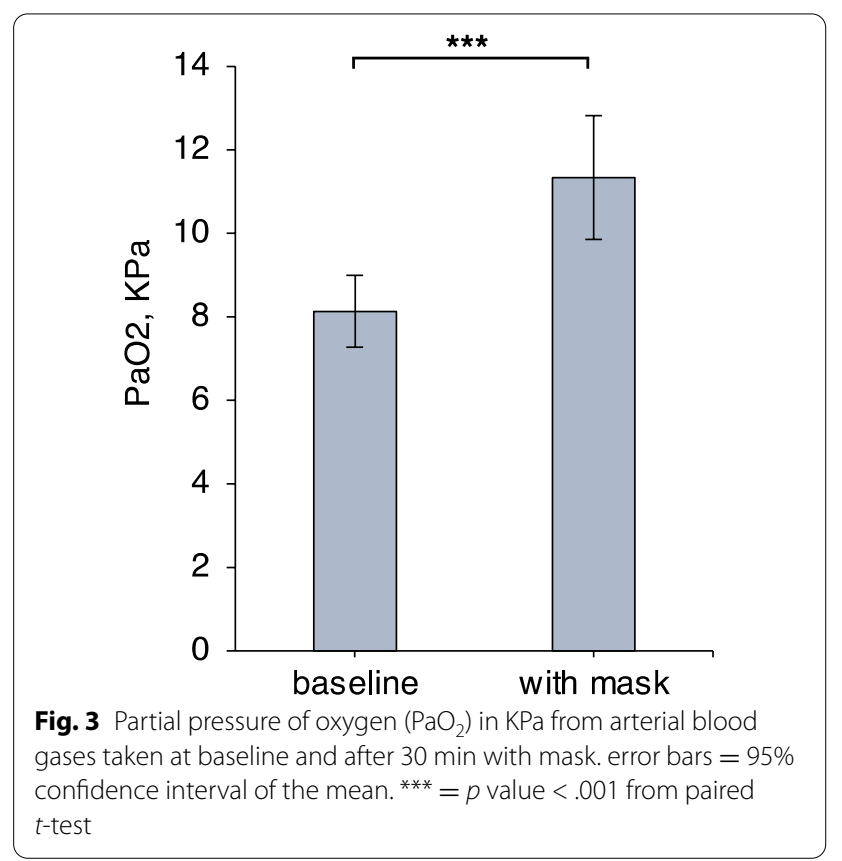


mouth-breathing or when exercise was used to simulate respiratory distress [7]. Whether this applies in COVID19 is uncertain.

It was beyond the scope of our research letter to study the underlying mechanism, and several concurrent processes may contribute. Therefore, we are sincerely grateful for all input in this matter, including that of $\mathrm{dr}$ Swenson [8]. Hopefully, further research in oxygen delivery in severe COVID-19 will elucidate this matter.

\section{Acknowledgements}

Not applicable.

\section{Authors' contributions}

RC wrote and reviewed the manuscript. RC drawn the figures presented in this manuscript. PB wrote and reviewed the manuscript. All authors read and approved the final manuscript.

\section{Funding}

No funding was required.

\section{Availability of data and materials}

Figures were drawn by the author/RC).

\section{Declarations}

Ethics approval and consent to participate

Not applicable.

\section{Consent for publication}

Not applicable.

\section{Competing interests}

The authors declare that they have no competing interests.
Received: 28 September 2021 Accepted: 29 September 2021

Published online: 16 November 2021

\section{References}

1. Dogani B, Månsson F, Resman F, Hartman H, Tham J, Torisson G. The application of an oxygen mask, without supplemental oxygen, improved oxygenation in patients with severe COVID-19 already treated with highflow nasal cannula. Crit Care. 2021;25(1):319.

2. Bohr C, Hasselbalch K, Krogh A. Über einen in biologischer Beziehung wichtigen Einfluss, den die Kohlensäurespannung des Blutes auf dessen Sauerstoffbindung übt (concerning a biologically important relationship - the influence of the carbon dioxide content of blood on its oxygen binding). Skand Arch Physiol. 1904;16:401-12.

3. Christiansen J, Douglas CG, Haldane JS. The absorption and dissociation of carbon dioxide by human blood. J Physiol. 1914;48:244-71.

4. MacDonald R. Red cell 2,3-diphosphoglycerate and oxygen affinity. Anaesthesia. 1977;32(6):544-53.

5. Born P Castro R. A combination of Bohr and Haldane effects provide a physiologic explanation for the increase in arterial oxygen saturation when a face mask is added to a high-flow nasal cannula in severely hypoxemic COVID-19 patients. Crit Care. 2021.

6. Montiel V, Robert A, Robert A, Nabaoui A, Marie T, Mestre NM, Guillaume M, Laterre PF, Wittebole X. Surgical mask on top of high-flow nasal cannula improves oxygenation in critically ill COVID-19 patients with hypoxemic respiratory failure. Ann Intensive Care. 2020;10(1):125.

7. Ritchie JE, Williams AB, Gerard C, Hockey H. Evaluation of a humidified nasal high-flow oxygen system, using oxygraphy, capnography and measurement of upper airway pressures. Anaesth Intensive Care. 2011;39(6):1103-1110.

8. Swenson ER. Does inspiration of exhaled $\mathrm{CO}_{2}$ explain improved oxygenation with a face mask plus high-flow nasal cannula oxygen in severe COVID-19 infection? Crit Care. 2021;25(1):343.

\section{Publisher's Note}

Springer Nature remains neutral with regard to jurisdictional claims in published maps and institutional affiliations.
Ready to submit your research? Choose BMC and benefit from:

- fast, convenient online submission

- thorough peer review by experienced researchers in your field

- rapid publication on acceptance

- support for research data, including large and complex data types

- gold Open Access which fosters wider collaboration and increased citations

- maximum visibility for your research: over $100 \mathrm{M}$ website views per year

At BMC, research is always in progress.

Learn more biomedcentral.com/submissions 